UDC: $631.452 ; 631.95$

\title{
FOCUS OF MINERALIZATION-SYNTHESIS PROCESSES OF THE ORGANIC MATTER IN THE LEACHED CHERNOZEM WHILE CULTIVATING POTATOES ON DIFFERENT FERTILIZATION BACKGROUNDS
}

\author{
V. V. Volkogon, O. V. Pyrig, S. B. Dimova, K. I. Volkogon \\ Institute of Agricultural Microbiology and Agroindustrial Manufacture, \\ the National Academy of Agrarian Sciences of Ukraine \\ 97, Shevchenka Str., Chernihiv, 14027 Ukraine
}

E-mail: *volkogon@ukr.net,altrochman1986@gmail.com,dimova13@ukr.net,katerina_volkogon@ukr.net

Received July 29, 2019 / Received October 07, 2020 / Accepted March 20, 2019

\begin{abstract}
Aim. To investigate the focus of the mineralization-synthesis processes in leached chernozem while cultivating potatoes in different fertilization systems, ensuring different supplies of raw organic matter into the soil. Methods. Field experiment, gas chromatography. Results. The study of emissions of nitrous oxide and carbon dioxide from the soil followed by the calculations of the specific losses of $\mathrm{N}-\mathrm{N}_{2} \mathrm{O}\left(\mathrm{g} / \mathrm{kg} \mathrm{C}-\mathrm{CO}_{2}\right)$, depending on fertilization system and in comparison with the indicators of the "reference" soil, provide an opportunity for rapid determination of the focus of the mineralization-synthesis processes in the organic matter in agrocenoses. The use of exclusively mineral fertilization systems results in the highest specific losses of $\mathrm{N}_{2} \mathrm{O}$ as the increase of the applied fertilizer doses initiates the mineralization processes in the soil. The combination of mineral fertilizers with raw organic products ( $5 \mathrm{t} / \mathrm{ha}$ straw and $13 \mathrm{t} / \mathrm{ha}$ of lupine cover crop) significantly improves the situation. At the same time, in experiment with the lowest $\left(\mathrm{N}_{40} \mathrm{P}_{40} \mathrm{~K}_{40} \mathrm{~kg} / \mathrm{ha}\right)$ and medium $\left(\mathrm{N}_{80} \mathrm{P}_{80} \mathrm{~K}_{80} \mathrm{~kg} / \mathrm{ha}\right)$ doses of mineral fertilizers the balance of mineralization-synthesis processes of organic matter was observed. The highest rate of mineral fertilizer dose in the experiment $\left(\mathrm{N}_{120} \mathrm{P}_{120} \mathrm{~K}_{120} \mathrm{~kg} / \mathrm{ha}\right)$, even in combination with the raw organic material, activates mineralization processes. With the use of manure, as well as upon its combination with the lupine cover crop and low doses of mineral fertilizers, the optimization of nitrous oxide and carbon dioxide emissions is observed. Conclusions. The use of solely mineral fertilizers in the technology of potato cultivation is inappropriate in terms of environmental reasons. The combination of mineral fertilizers (not exceeding $\mathrm{N}_{80} \mathrm{P}_{80} \mathrm{~K}_{80} \mathrm{~kg} /$ ha dose) with straw and lupine cover crop ensures optimization of the processes of mineralization-synthesis of organic matter. Moreover, the optimization of biological processes in the soil was observed in experiments with the use of manure, its combination with lupine cover crop and low doses of mineral fertilizers. The calculations of the indices of mineralization-synthesis of organic matter, considering the emission factors of $\mathrm{N}_{2} \mathrm{O}$ and $\mathrm{CO}_{2}$, obtained with the use of modern high-sensitivity gas chromatographic methods, allow to determine the focus of biological processes in the soil, depending on fertilization system, and to estimate ecologic sustainability of types and doses of fertilizers.
\end{abstract}

Key words: $\mathrm{N}_{2} \mathrm{O}$ emission, $\mathrm{CO}_{2}$ emission, mineral fertilizers, organic fertilizers, processes of mineralization and synthesis of organic matter, potatoes, fertilization systems.

DOI:

\section{INTRODUCTION}

It is known that in natural phytocenosis soils the processes of mortmass mineralization and synthesis of de novo organic matter are balanced, which en-

(C) V. V. VOLKOGON, O. V. PYRIG, S. B. DIMOVA, K. I. VOLKOGON, 2020 sures maintaining the stable humus content in them. On the contrary, due to anthropogenic impact arable soils are characterized by negative changes in both the resources of humus substances therein and their agronomic properties (Waksman S.A., 1952; Brock C. et. al, 2013). The fertilization system of agricultural crops is a special factor, impacting the humus state of agricul- 
tural lands. For instance, the excessive use of mineral fertilizers does not envisage the introduction of fresh organic matter (except for crop residue) which is the substrate for humus synthesis, has negative effect on the fraction-wise ratio of humic acids, conditions the weakening of their bond with $\mathrm{Ca}^{2+}$, leads to the increase in the motility and mineralization of humus constituents. The abovementioned results in gradual deterioration of soil fertility (Doran J.W. et al., 1996; Margdoff F. et al., 1997, Baliuk S. et al., 2014; Purtova L.N. et al., 2017). In some conditions, the additional application of organic materials (manure, straw, mass of cover crops, etc.) to fertilize agricultural crops and replenish soils with carbon promotes the domination of organic matter synthesis processes over its mineralization (Raupp J. et al., 2001; Baliuk et al., 2016; Purtova L.N., Kiseleva I.V., 2019). However, the consequences of the impact of agrotechnical technologies on the optimization of mineralization-synthesis processes and humus content are widely separated in time which hinders timely conclusions on the efficiency of specific measures.

Therefore, the express method of determining the focus of mineralization-synthesis processes of organic matter was suggested (Volkogon et al., 2019). Its essence lies in determining the emission of $\mathrm{N}_{2} \mathrm{O}$ and $\mathrm{CO}_{2}$ depending on the agrotechnology and subsequent calculations of specific losses of nitrogen gas (per unit of emission carbon dioxide) as well as mineralizationsynthesis indices for organic matter which take into account the intensity of processes in the soil of agrocenosis as compared to the "reference" soil (fallow, virgin land). Gas chromatography analysis of emission losses of nitrogen and carbon allows to determine timely and accurately which of the two processes (mineralization of organic matter or synthesis de novo) dominates in the soil.

Taking the abovementioned into consideration, the aim of our present research was to study the focus of mineralization-synthesis processes in leached chernozem while cultivating potatoes using the abovementioned methodological approaches (Volkogon et al., 2019).

\section{MATERIALS AND METHODS}

The study was conducted in 2016-2018 at the field long-term experiment of the Institute of Agricultural Microbiology and Agroindustrial Manufacture, the National Academy of Agrarian Sciences of Ukraine, initiated in 2009 on leached chernozem. The agrochemical characteristic of soil, determined by standard methods (Fomin G.S., Fomin A.G., 2000), demonstrates the fol- lowing indices: $\mathrm{pH}_{\text {sal }}-5.3$; humus content $-3.03 \%$; easily hydrolysable nitrogen $-95 \mathrm{mg} / \mathrm{kg}$ of soil; mobile phosphorus compounds $\left(\mathrm{P}_{2} \mathrm{O}_{5}\right)-150 \mathrm{mg} / \mathrm{kg}$ of soil; exchange potassium $\left(\mathrm{K}_{2} \mathrm{O}\right)-108 \mathrm{mg} / \mathrm{kg}$ of soil.

The following agricultural crops were cultivated during the experiment on 1 ha of short crop rotation: potatoes - spring barley - peas - winter wheat.

The potatoes were cultivated on different agrobackgrounds for the purposes of the study. This crop is a convenient study object, as its fertilization systems may be based on the application of both organic, mineral, and organo-mineral fertilizers which may ensure introduction of different fresh organic matter into soil and thus different focus of biological processes.

The cultivation of potatoes (after winter wheat) was done on the following agrobackgrounds: 1) no fertilizers (control); 2) straw; 3) intermediate cover crop; 4) manure; 5) straw + cover crop; 6) manure + cover crop; 7) $\mathrm{N}_{40} \mathrm{P}_{40} \mathrm{~K}_{40}$ (the application rate was $40 \mathrm{~kg} /$ ha of the active substance of each fertilizer); 8) $\mathrm{N}_{40} \mathrm{P}_{40} \mathrm{~K}_{40}+$ straw + cover crop; 9) $\mathrm{N}_{80} \mathrm{P}_{80} \mathrm{~K}_{80}$; 10) $\mathrm{N}_{80} \mathrm{P}_{80} \mathrm{~K}_{80}$ + straw + cover crop; 11) $\mathrm{N}_{120} \mathrm{P}_{120} \mathrm{~K}_{120}$; 12) $\mathrm{N}_{120} \mathrm{P}_{120} \mathrm{~K}_{120}$ + straw + cover crop; 13) manure $+\mathrm{N}_{40} \mathrm{P}_{40} \mathrm{~K}_{40}$;14) manure + cover crop $+\mathrm{N}_{40} \mathrm{P}_{40} \mathrm{~K}_{40}$.

The absolute control ("reference" plot) in the study was a fallow (since 2009) with the area of 0.75 ha, located next to the long-term field experiment.

In the corresponding variants of the experiment, $5 \mathrm{t} / \mathrm{ha}$ ground straw of winter wheat were incorporated into to the soil by disking immediately after harvesting. To receive green manure mass, blue lupine seeds were sown immediately after wheat harvesting and disking. In late autumn, the obtained green manure mass (13 t/ha) was incorporated to the soil by disking and subsequent ploughing. Cattle manure in the amount of $40 \mathrm{t} / \mathrm{ha}$ was incorporated to soil by tillage at the same time. The depth of tillage was $15 \mathrm{~cm}$.

Complex mineral fertilizers (the content of the active substance $-\mathrm{N}_{16} \mathrm{P}_{16} \mathrm{~K}_{16}$ ) were introduced in spring prior to cultivating potatoes according to the experiment scheme (40, 80 and $120 \mathrm{~kg} / \mathrm{ha}$ of the active substance).

The experiment was arranged in a completely randomized design with four repeats and the area of the experimental plot of 44.6 sq.m.

The closed chamber method (Hutchinson G.L. et al., 2000; Kusa K. et al., 2008; Zviagintzev, 1991) was used to estimate the emission of nitrous oxide and carbon dioxide in the "soil-plant" system after our modi- 
fication (Volkogon et al., 2019). This method involved the use of plastic 10-liter buckets, the bottom of which was drilled to install a rubber plug to isolate gases, and $50 \mathrm{ml}$ syringe was then used to take air samples.

The chambers were "installed" in soil at the depth of $5 \mathrm{~cm}$. A "water plug" was made around the chamber for better isolation of the system and prevention of the loss of gases, accumulated in the chambers. A weighing cup with water was put inside the chamber with the addition of 20 $\mathrm{g}$ calcium acetylide prior to the exposition (the reactions of calcium acetylide with water result in the formation of acetylene, inhibiting the enzyme of nitrous oxide reductase and terminating the process of dissimilation of $\mathrm{NO}_{3}^{-}$ and $\mathrm{NO}_{2}^{-}$at the stage of nitrous oxide reduction (Zviagintsev D.G., 1991). The exposition lasted three hours. The selected gas samples were placed into previously vacuumed vials with rubber plugs, taken to the laboratory and analyzed using gas chromatography.

The amount of $\mathrm{N}_{2} \mathrm{O}$ in the samples was detected using gas chromatograph Tsvet-500 M (Dzerzhinsk, Russia) with the electron capture detector. The 3meter-long steel sorption columns were filled with sorbent Paropak Q 60-80 mesh (Water Corporation, USA). The column temperature was $40{ }^{\circ} \mathrm{C}$, the evaporator temperature $-120{ }^{\circ} \mathrm{C}$, that of the detector $330{ }^{\circ} \mathrm{C}$. The amount of used carrier gas (argon with methane $95 / 5$ ) was $35 \mathrm{cc} / \mathrm{min}$.

The investigation on the content of $\mathrm{CO}_{2}$ in gas samples was conducted using gas chromatograph Tsvet-500 M with the thermal conductivity detector (bridge current of $130 \mathrm{~mA}$ ). The steel sorption columns were filled with sorbent Paropak Q 60-80 mesh. The temperature of columns was $25{ }^{\circ} \mathrm{C}$ and that of the detector $-40^{\circ} \mathrm{C}$. The amount of used carrier gas (helium) was $20 \mathrm{cc} / \mathrm{min}$.

The emission of $\mathrm{N}_{2} \mathrm{O}$ was estimated according to the formula:

$$
\frac{\mathrm{E} \times \mathrm{V}_{1}}{\mathrm{~V}_{2} \times \mathrm{S} \times \mathrm{t}},
$$

where $\mathrm{E}$ - amount of nitrous oxide in the sample under analysis, nmol $\mathrm{N}_{2} \mathrm{O} ; \mathrm{V}_{1}$ - volume of the chamber, cc; $\mathrm{V}_{2}$ - volume of the sample, introduced to the chromatograph, cc; $\mathrm{S}$ - area of cross section of the chamber, sq. $\mathrm{m}$.; $\mathrm{t}$ - exposition time.

The same formula was used to determine the emission of $\mathrm{CO}_{2}$, but $\mathrm{E}$ was estimated as the amount of carbon dioxide in the sample under analysis, nmol.

The indices of gas chromatography determination of the emission of $\mathrm{N}_{2} \mathrm{O}$ and $\mathrm{CO}_{2}$ were used to estimate the losses of nitrogen and carbon, taking into consideration the molecular mass of $\mathrm{N}_{2} \mathrm{O}$ and $\mathrm{CO}_{2}$ and the velocity of gas emission from one hectare in $24 \mathrm{~h}$.

The specific losses of $\mathrm{N}-\mathrm{N}_{2} \mathrm{O}$ were determined as the ratio of $\mathrm{g} \mathrm{N}-\mathrm{N}_{2} \mathrm{O} / \mathrm{kg} \mathrm{C}-\mathrm{CO}_{2}$. Based on the indices obtained, the mineralization-synthesis indices were estimated as the ratio of the module of the difference between the emission ratio $\mathrm{g} \mathrm{N}-\mathrm{N}_{2} \mathrm{O} / \mathrm{kg} \mathrm{C}-\mathrm{CO}_{2}$ of soil of the "reference" plot (fallow) and the soil of the agrocenosis to the emission ratio index $\mathrm{g} \mathrm{N}-\mathrm{N}_{2} \mathrm{O} / \mathrm{kg} \mathrm{C}-\mathrm{CO}_{2}$ of the "reference" plot:

$$
\mathrm{I}_{\mathrm{m}-\mathrm{s}}=\left(\mathrm{E}_{\text {r.p. }}-\mathrm{E}_{\text {agro }}\right) / \mathrm{E}_{\text {r.p. }}
$$

where $\mathrm{I}_{\mathrm{m}-\mathrm{s}}-$ mineralization-synthesis index; $\mathrm{E}_{\mathrm{r.p} .}-$ emission ratio of $\mathrm{g} \mathrm{N}-\mathrm{N}_{2} \mathrm{O} / \mathrm{kg} \mathrm{C}-\mathrm{CO}_{2}$ of the "reference" plot; $\mathrm{E}_{\text {agro }}$ - emission ratio of $\mathrm{g} \mathrm{N}-\mathrm{N}_{2} \mathrm{O} / \mathrm{kg} \mathrm{C}-\mathrm{CO}_{2}$ in the agrocenosis.

According to our method (Volkogon et al., 2019), the negative values of $\mathrm{I}_{\mathrm{m}-\mathrm{s}}$ index represent intense mineralization processes in soil. The approximation of index values to the zero index demonstrates the state of balance for the mineralization-synthesis processes. And index values above zero prove that synthetic processes in soil prevail over the mineralization processes.

The statistical processing of experimental data was conducted using disperse analysis and Microsoft Excel 2010.

\section{RESULTS OF INVESTIGATIONS}

The determination of gas emission from soil under potatoes during the emergence phase demonstrated the highest losses of $\mathrm{N}_{2} \mathrm{O}$ in variants with the introduction of manure into soil, its combination with green manure mass, organo-mineral fertilization (manure + $\mathrm{N}_{40} \mathrm{P}_{40} \mathrm{~K}_{40}$ ), and the highest dose of mineral fertilizers in the experiment (Table 1).

The lowest indices of nitrous oxide emission were registered in the fallow and the control variant (without fertilizers). However, the difference between the indices of the control and fallow is rather considerable which demonstrates the imbalance of biological processes in soil of agrocenosis even without the use of fertilizers.

First of all, $\mathrm{CO}_{2}$ emission increases after the introduction of fresh organic matter into soil in the form of manure, straw, green manure and their combinations. It is quite logical, considering the mineralization of the abovementioned organic materials. Noteworthy is another issue: the emission of carbon dioxide increases along with the increase in the doses of mineral 
fertilizers. For instance, at the introduction of $\mathrm{N}_{40} \mathrm{P}_{40} \mathrm{~K}_{40}$ into soil, the amount of $\mathrm{CO}_{2}$, released into the atmosphere, increases by $37.7 \%$ as compared to the index for the control, while using $\mathrm{N}_{80} \mathrm{P}_{80} \mathrm{~K}_{80}$ - by $62.7 \%$, and in case of the highest dose of fertilizers in the experiment the emission increases by $80.0 \%$. As there is no sufficient amount of fresh organic matter in soil (according to the scheme of the experiment it may be in these variants only in the form of roots or afterharvest residues of previous crops in the rotation), it may indicate the mineralization of conservative organic substances.

However, while assessing the dependence of the emission of investigated gases from soil depending on agrobackgrounds, the most interesting issue may be related to the emission ratio of $\mathrm{N}-\mathrm{N}_{2} \mathrm{O} / \mathrm{C}-\mathrm{CO}_{2}$, i.e. specific losses of nitrous oxide per unit of carbon dioxide. Thus, the estimation of absolute losses of $\mathrm{N}_{2} \mathrm{O}$ may bring us to the conclusion about ecological risks of manure. However, specific losses of nitrogen gas in this variant are some of the lowest in the experiment at the level of the control variant.

After the introduction of $5 \mathrm{t} / \mathrm{ha}$ of straw, the specific losses of nitrous oxide are lower as compared to the indices of the control variant and even the "reference" soil (fallow). It indicates intense immobilization of nitrogen compounds under these conditions.

There is some increase in specific losses of $\mathrm{N}_{2} \mathrm{O}$ in the variant with lupine mass which may be explained by rather rapid mineralization of this organic material and rather a high content of nitrogen compounds therein. However, the combination of lupine and straw eliminates these losses.

The highest specific losses of nitrous oxide are observed after the introduction of mineral fertilizers. It demonstrates that under deficiency of fresh organic matter in soil, the nitrogen fertilizers applied may not be effectively immobilized by microorganisms.

This conclusion is confirmed with the indices of specific losses of nitrogen gas on condition of combining mineral fertilizers with straw and green manure mass. For instance, after the introduction of low and medium doses of mineral nitrogen on the background of "straw + cover crop", specific losses of $\mathrm{N}_{2} \mathrm{O}$ decrease sharply and are even lower than the indices of the control variant. Nitrogen losses also decrease in case of combining the highest experimental dose of mineral fertilizers $\left(\mathrm{N}_{120} \mathrm{P}_{120} \mathrm{~K}_{120}\right)$ and fresh organic matter, but they still exceed control indices which evi-

Table 1. The emission ratio of gases and indices of the mineralization-synthesis of organic matter depending on fertilization for potatoes, the seedling phase, 2017

\begin{tabular}{l|c|c|c|c}
\hline \multicolumn{1}{c|}{ Experiment variants } & $\begin{array}{c}\text { Emission of } \mathrm{N}_{\mathrm{N}} \mathrm{O}, \\
\mathrm{g} / \mathrm{ha} \mathrm{in} 24 \mathrm{~h}\end{array}$ & $\begin{array}{c}\text { Emission of } \mathrm{C}-\mathrm{CO}_{2}, \\
\mathrm{~kg} / \mathrm{ha} \mathrm{in} 24 \mathrm{~h}\end{array}$ & $\begin{array}{c}\text { Emission ratio } \\
\text { of } \mathrm{N}_{-} \mathrm{N}_{2} \mathrm{O} / \mathrm{C}_{-} \mathrm{CO}_{2} *\end{array}$ & $\mathrm{I}_{\mathrm{m}-\mathrm{s}}$ \\
\hline No fertilizers, control & 93.15 & 57.50 & 1.62 & -0.15 \\
Straw & 98.91 & 75.50 & 1.31 & +0.07 \\
Cover crop & 151.25 & 84.50 & 1.79 & -0.27 \\
Manure & 226.00 & 138.45 & 1.63 & -0.16 \\
Straw + cover crop & 154.20 & 108.01 & 1.43 & -0.01 \\
Manure + cover crop & 219.80 & 144.05 & 1.53 & -0.08 \\
$\mathrm{~N}_{40} \mathrm{P}_{40} \mathrm{~K}_{40}$ & 171.4 & 79.20 & 2.16 & -0.53 \\
$\mathrm{~N}_{40} \mathrm{P}_{40} \mathrm{~K}_{40}+$ straw + cover crop & 178.90 & 130.90 & 1.37 & +0.03 \\
$\mathrm{~N}_{80} \mathrm{P}_{80} \mathrm{~K}_{80} 0$ & 207.68 & 93.55 & 2.22 & -0.57 \\
$\mathrm{~N}_{80} \mathrm{P}_{80} \mathrm{~K}_{80}+$ straw + cover crop & 183.90 & 122.52 & 1.50 & -0.06 \\
$\mathrm{~N}_{120} \mathrm{P}_{120} \mathrm{~K}_{120}$ & 238.05 & 103.50 & 2.30 & -0.63 \\
$\mathrm{~N}_{120} \mathrm{P}_{120} \mathrm{~K}_{120}+$ straw + cover crop & 207.80 & 111.90 & 1.86 & -0.32 \\
Manure $+\mathrm{N}_{40} \mathrm{P}_{40} \mathrm{~K}_{40} 0$ & 245.71 & 159.55 & 1.54 & -0.09 \\
Manure + cover crop $+\mathrm{N}_{40} \mathrm{P}_{40} \mathrm{~K}_{40}$ & 258.80 & 177.00 & 1.46 & -0.04 \\
Fallow & 29.20 & 20.70 & 1.41 & 0 \\
LSD & 15.35 & 9.20 & & \\
\hline
\end{tabular}

Note. $*$ - specific losses of $\mathrm{N}_{2} \mathrm{O}$ (in g per $\mathrm{kg} \mathrm{CO}_{2}$ ). 


\section{VOLKOGON et al.}

dently demonstrates the excess of nitrogen fertilization for potatoes.

The indices of mineralization-synthesis $\left(\mathrm{I}_{\mathrm{m}-\mathrm{s}}\right)$, as an integral index of these processes compared to the data of both the control and the fallow [8], demonstrate the formation of predominantly synthetic processes (indices with "+") in the variants with the introduction of straw and in case of using $\mathrm{N}_{40} \mathrm{P}_{40} \mathrm{~K}_{40}$ in the combination with straw and green manure. The indices of $\mathrm{I}_{\mathrm{m}-\mathrm{s}}$, close to the value of the "reference" soil, are also present in the variants "straw + green manure", "manure + green manure", " $\mathrm{N}_{40} \mathrm{P}_{40} \mathrm{~K}_{40}+$ straw + green manure", as well as "manure + green manure $+\mathrm{N}_{40} \mathrm{P}_{40} \mathrm{~K}_{40}$ " and "manure $+\mathrm{N}_{40} \mathrm{P}_{40} \mathrm{~K}_{40}$ ”.

After the introduction of mineral fertilizers only, the indices of mineralization-synthesis of organic matter demonstrate the prevalence of mineralization processes (Table 1).

During the second term of observations (the phase of potato flowering), we observe a similar character of mineralization and synthesis processes in soil depending on the fertilization for the crop (Table 2).

At the same time, in the variants with the introduction of straw, the combination of $\mathrm{N}_{40} \mathrm{P}_{40} \mathrm{~K}_{40}$ with straw and green manure and in case of using manure along with the cover crop and the introduction of $\mathrm{N}_{40} \mathrm{P}_{40} \mathrm{~K}_{40}$, the increase in synthesis processes was observed (indices of $I_{m-s}$ with " + " increase). There was also a decrease in the intensity of mineralization processes in the variants with the introduction of mineral fertilizers $\left(\mathrm{I}_{\mathrm{m}-\mathrm{s}}\right.$ with the value "-" decreased as compared to the indices, registered in the initial phases of plant organogenesis).

It should be noted that during this period in the variant " $\mathrm{N}_{80} \mathrm{P}_{80} \mathrm{~K}_{80}+$ straw + green manure" the index of mineralization-synthesis of organic matter had almost no differences from the index for the fallow $(-0.01$ against 0 ), which demonstrated the optimization of mineralization-synthesis processes under these conditions.

Positive changes can also be observed in the variant with the introduction of the highest experimental dose of fertilizers, but even the combination of fertilizers and additional organic matter was not capable of ensuring optimal ratio of mineralization and synthetic processes.

At the completion of vegetation period of potatoes, the determination of the emission of $\mathrm{N}_{2} \mathrm{O}$ and $\mathrm{CO}_{2}$, and estimation of their emission ratio and the indices of mineralization-synthesis of organic matter generally yielded findings, similar to the abovementioned (Ta-

Table 2. The indices of mineralization-synthesis of organic matter in soil under potatoes on different agrobackgrounds, the phase of flowering, 2017

\begin{tabular}{|c|c|c|c|c|}
\hline Experiment variants & $\begin{array}{c}\text { Emission of } \mathrm{N}^{-\mathrm{N}_{2} \mathrm{O}} \\
\mathrm{g} / \mathrm{ha} \text { in } 24 \mathrm{~h}\end{array}$ & $\begin{array}{c}\text { Emission of C-CO } \\
\mathrm{kg} / \mathrm{ha} \text { in } 24 \mathrm{~h}\end{array}$ & $\begin{array}{c}\text { Emission ratio } \\
\text { of } \mathrm{N}-\mathrm{N}_{2} \mathrm{O} / \mathrm{C}-\mathrm{CO}_{2}{ }^{*}\end{array}$ & $\mathrm{I}_{\mathrm{m}-\mathrm{s}}$ \\
\hline No fertilizers, control & 91.60 & 45.40 & 2.02 & -0.17 \\
\hline Straw & 98.90 & 66.5 & 1.49 & +0.14 \\
\hline Cover crop & 152.50 & 71.8 & 2.12 & -0.23 \\
\hline Manure & 219.20 & 99.1 & 2.21 & -0.29 \\
\hline Straw + cover crop & 147.10 & 80.9 & 1.82 & -0.06 \\
\hline Manure + cover crop & 205.10 & 117.3 & 1.75 & -0.02 \\
\hline $\mathrm{N}_{40} \mathrm{P}_{40} \mathrm{~K}_{40}$ & 162.20 & 71.8 & 2.30 & -0.33 \\
\hline $\mathrm{N}_{40} \mathrm{P}_{40} \mathrm{~K}_{40}+$ straw + cover crop & 164.90 & 108.2 & 1.52 & +0.11 \\
\hline $\mathrm{N}_{80} \mathrm{P}_{80} \mathrm{~K}_{80} 0$ & 191.50 & 78.7 & 2.43 & -0.41 \\
\hline $\mathrm{N}_{80} \mathrm{P}_{80} \mathrm{~K}_{80}+$ straw + cover crop & 170.10 & 97.6 & 1.74 & -0.01 \\
\hline $\mathrm{N}_{120} \mathrm{P}_{120} \mathrm{~K}_{120}$ & 211.10 & 83.2 & 2.54 & -0.47 \\
\hline $\mathrm{N}_{120} \mathrm{P}_{120} \mathrm{~K}_{120}+$ straw + cover crop & 196.90 & 93.8 & 2.10 & -0.22 \\
\hline Manure $+\mathrm{N}_{40} \mathrm{P}_{40} \mathrm{~K}_{40} 0$ & 254.10 & 123.3 & 2.06 & -0.20 \\
\hline Manure + cover crop $+\mathrm{N}_{40} \mathrm{P}_{40} \mathrm{~K}_{40}$ & 232.60 & 152.8 & 1.52 & +0.12 \\
\hline Fallow & 28.40 & 16.51 & 1.72 & 0 \\
\hline $\mathrm{LSD}_{05}$ & 14.18 & 9.05 & & \\
\hline
\end{tabular}


ble 3). However, during this period there is a tendency towards domination of mineralization processes in the variants with previously determined prevalence of organic matter synthesis.

In case of introducing the additional organic matter in the form of straw into soil, while combining the lowest experiment dose of fertilizers and green manure, or combination of manure and green manure with the lowest experiment dose of mineral fertilizers, during flowering phase the indices of mineralization-synthesis of organic matter are negative (although the difference from the fallow index is insignificant).

At the same time, negative values of $\mathrm{I}_{\mathrm{m}-\mathrm{s}}$ in the variants with the introduction of fertilizers increase considerably. It should be noted though that the combination of fertilizers, straw and green manure changes the index under investigation considerably (Table 3 ).

Therefore, the application of mineral systems of fertilization while cultivating potatoes on leached chernozem leads to initiating mineralization processes in soil. The combination of fertilizers and additional organic matter in the form of straw and green manure improves the situation considerably. At the same time, the lowest $\left(\mathrm{N}_{40} \mathrm{P}_{40} \mathrm{~K}_{40}\right)$ and medium $\left(\mathrm{N}_{80} \mathrm{P}_{80} \mathrm{~K}_{80}\right)$ experiment doses of mineral fertilizers are characterized by optimal in- dices of the balance of mineralization-synthesis processes of organic matter.

The highest dose of mineral fertilizers $\left(\mathrm{N}_{120} \mathrm{P}_{120} \mathrm{~K}_{120}\right)$, even in combination with $5 \mathrm{t} / \mathrm{h}$ a straw and $13 \mathrm{t} / \mathrm{ha}$ green manure, activates mineralization processes.

There is a noted optimization of the investigated processes in case of combining manure and $\mathrm{N}_{40} \mathrm{P}_{40} \mathrm{~K}_{40}$ and especially when these fertilizers are combined with lupine mass.

The investigations, conducted in other periods (2016 and 2018), confirm the abovementioned dependences in the focus of the processes of mineralizationsynthesis of organic matter depending on the agrobackground.

Improving the nutrition for potato plants using orga-nic, mineral and organo-mineral fertilization has positive impact on the productivity of the crop (Table 4).

At the same time, mere introduction of $5 \mathrm{t} / \mathrm{ha}$ of straw does not ensure a significant surplus of crop productivity. Still, the combination of straw and green manure promotes a considerable increase in agrocenosis productivity. The most effective ways to impact the productivity of potatoes were found to be as follows: the introduction of manure - gain of $9.8 \mathrm{t} / \mathrm{ha}$, combined

Table 3. The focus of the processes of mineralization-synthesis of organic matter in soil under potatoes, the phase of potato vine dying-off, 2017

\begin{tabular}{l|c|c|c|c}
\hline \multicolumn{1}{c|}{ Experiment variants } & $\begin{array}{c}\text { Emission of } \mathrm{N}_{\mathrm{N}} \mathrm{O}, \\
\mathrm{g} / \mathrm{ha} \mathrm{in} 24 \mathrm{~h}\end{array}$ & $\begin{array}{c}\text { Emission of C-CO } \\
\mathrm{kg} / \mathrm{ha} \mathrm{in} 24 \mathrm{~h}\end{array}$ & $\begin{array}{c}\text { Emission ratio } \\
\text { of } \mathrm{N}_{2} \mathrm{O} / \mathrm{C}_{-} \mathrm{CO}_{2}{ }^{*}\end{array}$ & $\mathrm{I}_{\mathrm{m}-\mathrm{s}}$ \\
\hline No fertilizers, control & 83.80 & 36.20 & 2.31 & -0.42 \\
Straw & 85.50 & 51.41 & 1.66 & -0.02 \\
Cover crop & 145.10 & 62.00 & 2.34 & -0.44 \\
Manure & 203.30 & 85.5 & 2.38 & -0.46 \\
Straw + cover crop & 138.90 & 71.05 & 1.96 & -0.20 \\
Manure + cover crop & 188.60 & 93.38 & 2.03 & -0.25 \\
$\mathrm{~N}_{40} \mathrm{P}_{40} \mathrm{~K}_{40}$ & 146.00 & 59,30 & 2.46 & -0.51 \\
$\mathrm{~N}_{40} \mathrm{P}_{40} \mathrm{~K}_{40}+$ straw + cover crop & 150.00 & 90.81 & 1.65 & -0.02 \\
$\mathrm{~N}_{80} \mathrm{P}_{80} \mathrm{~K}_{80} 0$ & 174.60 & 67.30 & 2.59 & -0.59 \\
$\mathrm{~N}_{80} \mathrm{P}_{80} \mathrm{~K}_{80}+$ straw + cover crop & 161.20 & 87.40 & 1.85 & -0.14 \\
$\mathrm{~N}_{120} \mathrm{P}_{120} \mathrm{~K}_{120}$ & 196.10 & 73.42 & 2.67 & -0.64 \\
$\mathrm{~N}_{120} \mathrm{P}_{120} \mathrm{~K}_{120}+$ straw + cover crop & 183.90 & 83.00 & 2.22 & -0.36 \\
Manure $+\mathrm{N}_{40} \mathrm{P}_{40} \mathrm{~K}_{40} 0$ & 232.20 & 105.90 & 2.19 & -0.35 \\
Manure + cover crop $+\mathrm{N}_{40} \mathrm{P}_{40} \mathrm{~K}_{40}$ & 219.80 & 128.60 & 1.71 & -0.05 \\
Fallow & 25.70 & 15.8 & 1.63 & 0 \\
LSD & 12.40 & 4.72 & & \\
\hline
\end{tabular}


application of manure and green manure - productivity increase by $11.0 \mathrm{t} / \mathrm{ha}$; the introduction of $\mathrm{N}_{80} \mathrm{P}_{80} \mathrm{~K}_{80}$ (gain of $11.6 \mathrm{t} / \mathrm{ha}$ ) and especially the combination with straw and lupine mass $(16.1 \mathrm{t} / \mathrm{ha})$; the introduction of $\mathrm{N}_{120} \mathrm{P}_{120} \mathrm{~K}_{120}$ (increase in productivity by $16.2 \mathrm{t} / \mathrm{ha}$ ) and especially in the combination with fresh organic matter (gain to the control at the level of $21.2 \mathrm{t} / \mathrm{ha}$ ).

High indices of productivity were also obtained in case of combining manure with mineral fertilizers (gain of $16.4 \mathrm{t} / \mathrm{ha}$ ), and combining manure with green manure mass and mineral fertilizers in the dose of $\mathrm{N}_{40} \mathrm{P}_{40} \mathrm{~K}_{40}$ (gain of $18.6 \mathrm{t} / \mathrm{ha}$ ).

However, the comparison of crop productivity rates against the indices of the focus of mineralization-synthesis process demonstrates the compromise between economic effect and ecologic requirements only for the use of organic fertilizers and organo-mineral fertilization. After the introduction of mineral fertilizers, there are considerable losses of nitrogen compounds and high emission of $\mathrm{CO}_{2}$ which may demonstrate enhanced dehumification processes under these conditions. At the same time, the addition of organic fertilizers to mineral fertilization of the crop ensures the optimization of investigated indices. Only in case of using the highest experiment dose of fertilizers $\left(\mathrm{N}_{120} \mathrm{P}_{120} \mathrm{~K}_{120}\right)$ this addition was not capable of changing the focus of the investigated biological processes in soil completely.

\section{DISCUSSION OF RESULTS}

It should be highlighted that a famous agrochemical statement (Doran J.W. et al., 1996; Baliuk S. et al., 2014) regarding the decrease in soil fertility due to limited introduction of fresh organic matter thereinto is supplemented by our findings of determining the focus of biological processes of mineralization-synthesis of organic matter. In addition, the discussion point about the conclusions of some researchers (Doran J.W. et al., 1996; Margdoff F. et al., 1997; Purtova L.N. et al., 2016) regarding the destructive impact of mineral fertilization systems for agricultural crops on the humus state of soils is confirmed with the data of gas chromatography determination of the emission of $\mathrm{N}_{2} \mathrm{O}$ and $\mathrm{CO}_{2}$ and subsequent calculations of the specific losses of $\mathrm{N}_{-} \mathrm{N}_{2} \mathrm{O}$ and indices of mineralization--synthesis of organic matter. Contrary to classic agrochemical technologies, the application of which allows determining the prevalence of synthetic (or mineralization) processes in soil on condition of adhering to specific fertilization systems for quite a long time (sometimes the verification of this conclusion requires decades), the calculations of $\mathrm{I}_{\mathrm{m}-\mathrm{s}}$ ensure timely and accurate results (it should be noted that gas chromatography (with electron capture detector) determination of the emission of $\mathrm{N}_{2} \mathrm{O}$ allows detecting changes at the level of $10^{-12} \mathrm{~mol}$ of nitrogen). We do not reject the need for classic agrochemical methods, but believe that the methodological

Table 4. The yield of potatoes depending on the agrobackground (average for three years)

\begin{tabular}{|c|c|c|c|}
\hline \multirow{2}{*}{ Experiment variants } & \multirow{2}{*}{ Yield, tons/ha } & \multicolumn{2}{|c|}{ Gain against the control } \\
\hline & & $\mathrm{t} / \mathrm{ha}$ & $\%$ \\
\hline No fertilizers (control) & 13.0 & - & - \\
\hline Straw & 13.4 & 0.4 & 3.1 \\
\hline Cover crop & 14.6 & 1.6 & 12.3 \\
\hline Manure & 22.8 & 9.8 & 75.4 \\
\hline Straw + cover crop & 16.2 & 3.2 & 24.6 \\
\hline Manure + cover crop & 24.0 & 11.0 & 84.6 \\
\hline $\mathrm{N}_{40} \mathrm{P}_{40} \mathrm{~K}_{40}$ & 15.7 & 2.7 & 20.8 \\
\hline $\mathrm{N}_{40} \mathrm{P}_{40} \mathrm{~K}_{40}+$ straw + cover crop & 21.1 & 8.1 & 62.3 \\
\hline $\mathrm{N}_{80} \mathrm{P}_{80} \mathrm{~K}_{80} 0$ & 24.6 & 11.6 & 89.2 \\
\hline $\mathrm{N}_{80} \mathrm{P}_{80} \mathrm{~K}_{80} 0+$ straw + cover crop & 29.1 & 16.1 & 123.8 \\
\hline $\mathrm{N}_{120} \mathrm{P}_{120} \mathrm{~K}_{120} 0$ & 29.2 & 16.2 & 124.6 \\
\hline $\mathrm{N}_{120} \mathrm{P}_{120} \mathrm{~K}_{120} 0+$ straw + cover crop & 34.2 & 21.2 & 163.1 \\
\hline Manure $+\mathrm{N}_{40} \mathrm{P}_{40} \mathrm{~K}_{40}$ & 29.4 & 16.4 & 126.2 \\
\hline Manure + cover crop $+\mathrm{N}_{40} \mathrm{P}_{40} \mathrm{~K}_{40}$ & 31.6 & 18.6 & 143.1 \\
\hline $\mathrm{LSD}_{05}$ & 1.13 & & \\
\hline
\end{tabular}


approaches, suggested by us, may be a reliable addition to the existing ones and may be useful for express determination of ecologic perspectives of fertilization systems for agricultural crops.

\section{CONCLUSIONS}

According to our findings, the use of solely mineral fertilizers in the technology of potato cultivation is inappropriate in terms of environmental reasons. Organo-mineral fertilization ensures the optimization of the course of the processes of mineralization-synthesis of organic matter, but exceeding the dose of $\mathrm{N}_{80} \mathrm{P}_{80} \mathrm{~K}_{80}$ is unfavorable.

The methodological technologies, used in the investigations, may serve as a relevant supplement to current agrochemical methods of assessing agronomic measures, whose results are remote in time. Considering rather low sensitivity of determining the carbon content in soil, the statements about its quantitative changes below $5 \%$ may be rather doubtful. The calculations of the indices of mineralization-synthesis of organic matter while using modern high-sensitivity gas chromatographic methods to determine the emission of $\mathrm{N}_{2} \mathrm{O}$ and $\mathrm{CO}_{2}$ allow to determine the focus of biological processes in the soil timely and accurately, depending on fertilization, and to estimate ecologic sustainability of types and doses of fertilizers.

Adherence to ethical principles. This article does not relate to any studies using humans and animals as investigation subjects.

Conflict of interests. The authors deny any conflict of interests.

Financing. This study did not receive any specific grant from the financing institutions in state, commercial or non-commercial sectors.

\section{Спрямованість процесів мінералізації-синтезу органічної речовини в чорноземі вилуженому за різних систем удобрення картоплі}

В. В. Волкогон, О. В. Пиріг, С. Б. Дімова, К. І. Волкогон

Інститут сільськогосподарської мікробіології та агропромислового виробництва

Національної академії аграрних наук України

97, вул. Шевченка, Чернігів, 14027, Україна

E-mail:*volkogon@ukr.net, altrochman1986@gmail.com, dimova13@ukr.net, katerina_volkogon@ukr.net

Мета. Дослідити спрямованість процесів мінералізаціїсинтезу в чорноземі вилуженому при вирощуванні картоплі за систем удобрення культури, що передбачають різне забезпечення грунту свіжою органічною речови- ною. Методи. Польовий дослід, газохроматографічні. Результати. Дослідження емісії закису азоту і вуглекислого газу з грунту та наступні розрахунки питомих втрат $\mathrm{N}-\mathrm{N}_{2} \mathrm{O}$ (г/кг C- $\mathrm{CO}_{2}$ ), залежно від систем удобрення і в порівнянні з показниками «еталонного» грунту, дають можливість швидкого визначення спрямованості процесів мінералізації-синтезу органічної речовини в агроценозах. Використання виключно мінеральних систем удобрення призводить до найбільших питомих втрат $\mathrm{N}_{2} \mathrm{O}$. Зростання норм туків ініціює розвиток мінералізаційних процесів у грунті. Поєднання мінеральних добрив 3 додатковою органічною речовиною (5 т/га соломи та 13 т/га маси люпинового сидерату) суттєво покращує ситуацію. При цьому найменша $\left(\mathrm{N}_{40} \mathrm{P}_{40} \mathrm{~K}_{40}\right) \mathrm{i}$ середня $\left(\mathrm{N}_{80} \mathrm{P}_{80} \mathrm{~K}_{80}\right)$ в досліді норми мінеральних добрив характеризуються збалансованістю процесів мінералізації-синтезу органічної речовини. Найвища в досліді норма туків $\left(\mathrm{N}_{120} \mathrm{P}_{120} \mathrm{~K}_{120}\right)$, навіть за iї поєднання зі свіжою органічною речовиною, призводить до активізації мінералізаційних процесів. За використання гною, a також за його поєднання 3 сидеральною масою та невисокими нормами мінеральних добрив спостерігається оптимізація досліджуваних процесів. Висновки. Використання лише мінеральних добрив при вирощуванні картоплі недоцільне з екологічних міркувань. Поєднання туків з соломою і сидеральною масою забезпечує оптимізацію перебігу процесів мінералізації-синтезу органічної речовини, проте перевищення їх норми понад $\mathrm{N}_{80} \mathrm{P}_{80} \mathrm{~K}_{80} \in$ небажаним. Оптимізація біологічних процесів у грунті досягається за використання гною, його поєднання 3 сидератом, а також 3 невисокою нормою мінеральних добрив. Розрахунки індексів мінералізації-синтезу органічної речовини, що враховують показники емісії $\mathrm{N}_{2} \mathrm{O}$ і $\mathrm{CO}_{2}$, отримані за використання сучасних високочутливих газохроматографічних методів, дозволяють визначити спрямованість біологічних процесів у грунті залежно від удобрення та оцінити екологічну доцільність видів і норм добрив.

Ключові слова: емісія $\mathrm{N}_{2} \mathrm{O}$ і $\mathrm{CO}_{2}$, мінеральні та органічні добрива, процеси мінералізації і синтезу органічної речовини, картопля, системи удобрення.

Направленность процессов минерализации-синтеза органического вещества в черноземе выщелоченном при разных системах удобрения картофеля

В. В. Волкогон, А. В. Пирог,

С. Б. Димова, Е. И. Волкогон

Институт сельскохозяйственной микробиологии и агропромышленного производства Национальной академии аграрных наук Украины 97, ул. Шевченко, г. Чернигов, 14027, Украина

Цель. Исследовать направленность процессов минерализации-синтеза в черноземе выщелоченном при выращивании картофеля с применением систем удобрения, 
предусматривающих разное обеспечение почвы свежим органическим веществом. Методы. Полевого опыта, газохроматографические. Результаты. Исследование эмиссии закиси азота и углекислого газа из почвы и последующие расчеты удельных потерь $\mathrm{N}-\mathrm{N}_{2} \mathrm{O}$ (г/кг $\left.\mathrm{C}-\mathrm{CO}_{2}\right)$ в зависимости от систем удобрения и по сравнению с показателями «эталонной» почвы, дают возможность быстро определять направленность процессов минерализации-синтеза органического вещества в агроценозах. Использование исключительно минеральных систем удобрения приводит к наибольшим удельным потерям $\mathrm{N}_{2} \mathrm{O}$. Увеличение норм туков инициирует развитие минерализационных процессов в почве. Сочетание минеральных удобрений с дополнительным органическим веществом (5 т/га соломы и 13 т/га массы люпинового сидерата) существенно улучшает ситуацию. При этом наименьшая $\left(\mathrm{N}_{40} \mathrm{P}_{40} \mathrm{~K}_{40}\right)$ и средняя $\left(\mathrm{N}_{80} \mathrm{P}_{80} \mathrm{~K}_{80}\right)$ в опыте нормы минеральных удобрений характеризуются сбалансированностью процессов минерализациисинтеза органического вещества. Применение наиболее высокой в опыте норма туков $\left(\mathrm{N}_{120} \mathrm{P}_{120} \mathrm{~K}_{120}\right)$, даже при ее сочетании со свежим органическим веществом, приводит к активизации минерализационных процессов. При использовании навоза, а также при его сочетании с сидеральной массой и невысокими нормами минеральных удобрений наблюдается оптимизация исследуемых процессов. Выводы. Использование только минеральных удобрений при выращивании картофеля нецелесообразно по экологическим соображениям. Сочетание туков с соломой и сидеральной массой обеспечивает оптимизацию протекания процессов минерализациисинтеза органического вещества, однако превышение их нормы более $\mathrm{N}_{80} \mathrm{P}_{80} \mathrm{~K}_{80}$ нежелательно. Оптимизация биологических процессов в почве достигается при использовании навоза, его сочетания с сидератом, а также с невысокой нормой минеральных удобрений. Расчеты индексов минерализации-синтеза органического вещества, базирующиеся на показателях эмиссии $\mathrm{N}_{2} \mathrm{O}$ и $\mathrm{CO}_{2}$, полученных при использовании современных высокочувствительных газохроматографических методов, позволяют оперативно определить направленность биологических процессов в почве в зависимости от удобрения и оценить экологическую целесообразность видов и норм удобрений.

Ключевые слова: эмиссия $\mathrm{N}_{2} \mathrm{O}$ и $\mathrm{CO}_{2}$, минеральные и органические удобрения, процессы минерализации и синтеза органического вещества, картофель, системы удобрения.

\section{REFERENCES}

Baliuk SA, Nosko BS, Skrylnyk EV. (2016) Modern problems of biological degradation of chernozem and the ways of preserving their fertility. Visnyk ahrarnoi nauky. (1):117. https://doi.org/10.31073/agrovisnyk201601-02.

Baliuk S, Kucher A, Anisimova O. (2014) Strategic priorities of economic provisions for reproduction of soil fertility. Adv. Sci. J. (9):178-82. http://www.natural-sciences.ru/ $\mathrm{ru} /$ article/view?id=36123.

Brock C, Franko U, Oberholzer HR, Kuka K, Leithold G, Kolbe H, Reinhold J. (2013) Humus balancing in Central Europe concepts, state of the art, and further challenges. J. Plant Nutrit. Soil Sci. 176:3-11. https://doi.org/10.1002/jpln.201200137.

Doran JW, Sarrantonio A, Liebig MA. (1996) Soil health and sustainable. Adv. Agronom. 56:1-54. http://dx.doi. org/10.1016/S0065-2113(08)60178-9.

Fomin GS, Fomin AG. (2000) Soil. Quality control and ecological safety by international standards. M.: Protector. 298 p. [in Russian].

Hutchinson GL, Livingston GP, Healy RW, Striegl RC. (2000) Chamber measurement of surface-atmosphere trace gas exchange: numerical evaluation of dependence on soil, interfacial layer, and source sink properties. J. Geoph. Res. 105(D7):8865-75. https:/doi.org/ 10.1029/1999JD901204.

Kusa K, Sawamoto T, Hu R, Hatano R. (2008) Comparison of the closed-chamber and gas concentration gradient methods for measurement of $\mathrm{CO}_{2}$ and $\mathrm{N}_{2} \mathrm{O}$ fluxes in two upland field soils. Soil Sci. Plant Nutrit. 54(5):777-85. https://doi.org/10.1111/j.1747-0765.2008.00292.x.

Margdoff F, Lanyon L, Liebhardt B. (1997) Nutrients cycling, transformations and flows: implications for a more sustainable agriculture. Adv. Agronom. 60:2-73.

Purtova LN, Kostenkov NM, Shchapova LN. (2017) Assessment of humus state and production of $\mathrm{CO}_{2}$ by soils of natural and agrogenic landscapes of the south of the Far East of Russia. Pochvovedenie. 50(1):1-8. doi: 10.1134/ S1064229317010124.

Purtova LN, Kiseleva IV. (2019) Impact of phytomelioration on fertility parameters and integral manifestation of Primorye soils. Vestnik DVO RAN., (1):51-7. doi: 10.2580 8/08697698.2019.203.1.006.

Raupp J. (2001) Manure fertilization for soil organic matter maintenance and its effects upon crops and environment, evaluated in a long time trial. Sustainable management of soil organic matter. UK: CAB international. 301-6 p.

Volkogon VV, Pyrig OV, Volkogon KI, Dimova SB. (2019) Methodological aspects of determining the processes of organic matter mineralization-synthesis in croplands. Agric. Sci. Pract. 6(1):3-9. https://doi.org/10.15407/ agrisp6.01.003.

Waksman SA. (1952) Soil microbiology. London: Chapman\&Hall, Limited. 356 p. https://doi.org/10.1002/jpln. 19540660213.

Zviagintsev DG. (1991) Methods of soil microbiology and biochemistry. M.: MGU,304 p. [in Russian]. 